\title{
Competing Models of Journalism? \\ Anglo-American and European Reporting in the Information Age ${ }^{1}$
}

\section{BY KEVIN WILLIAMS}

Anglo-American values and methods dominate our understanding of contemporary journalism. European journalism is seen as gradually importing Anglo-American practice, style and form in the twentieth century. The European model of journalism is portrayed as regressive, resistant to giving up the old ways - a model of how not to practice the profession. This article examines the features that distinguish the European model, including the close relationship with the political world, the focus on commentary, interpretation and advocacy and the commitment to 'literary' writing. It argues that in spite of the differences in how journalism is practiced in various European countries it is possible to identify a form of journalism, which is more literary, political and intellectual in its approach. The distinctiveness of this approach is being eroded with the incorporation of Anglo-American values and practices into education programmes, the commercialisation of the industry and the process of globalisation. However, the extent to which journalism in Europe is replicating the Anglo-American model is open to question. The European tradition remains firmly entrenched, especially in some countries such as France, Italy and Spain. It is also argued that the European model is becoming more relevant in the attempt of the profession to adjust to the complexities and changes of the information age. 
Journalism is often described as an Anglo-American invention (Chalaby, 1996; Tunstall, 1977: chapter 1). The modern conception of news and the practices of reporting and interviewing that characterise contemporary journalism are attributed to developments in American and British society. New techniques pioneered by US newspapers in the mid Victorian period are seen as introduced into the British press in the 1880 s where they were refined and enhanced by the 'Northcliffe revolution' of the early $20^{\text {th }}$ century. The development of journalism in the $20^{\text {th }}$ century is characterised by the gradual absorption of Anglo-American practice, style and form. As Mark Deuze (2005: 444) puts it: "the $20^{\text {th }}$ century history of ... journalism can be typified by the consolidation of a consensual occupational ideology among journalists in different parts of the world". By the end of the century the Anglo-American way of doing journalism had come to be considered as the universal yard stick by which the profession should be practiced. British and American news organisations, news agencies and newspapers dominate the flow of news around the world (Machin and Tunstall, 1999: chapter 8) and journalists as voracious consumers of global news increasingly looked to these organisations and publications to provide them with the model of how they should understand their role in society and how they should do their job.

Understanding of the profession of journalism is determined by the Anglo-American model of fact-based, news driven, objective reporting. The hegemony of the Anglo-American model - also described as the 'professional' or 'liberal' model - is sustained by the role of English as a world language, the concentration of academic and textbook publishing in Britain and America and the long tradition of journalism training and research in the US (Joesphi, 2005: 576). The "self absorption and parochialism" of much of the study of the mass media and journalism scholarship has been criticised by James Curran and Myung-Jin Park (2000: 3) who refer to the "routine" way in which "universalistic observations about the media" are "advanced in English-language books on the basis of evidence from a tiny handful of countries". John Downing (1996: xi) emphasises the conceptual impoverishment 
of extrapolating theoretically from such unrepresentative nations as Britain and the United States. By prescribing Anglo-American model as the only valid way of practicing the profession other journalism traditions have been ignored or neglected.

Some scholars have recently attempted to explore other models of journalism (for example, de Burgh, 2005; Hoyer and Pottker, 2005). They have emphasised - or perhaps more appropriately re-emphasised - the role of the nation-state in understanding the theory and practice of journalism. By asserting that national cultures, polities and societies shape the practice and performance of journalism they have highlighted the limits of 'Anglo-Americanisation' and shown that "ways of understanding the world's media systems are unduly influenced by the experience of a few, untypical countries" (Curran and Park, 2000: 15). However, such analysis is problematic on two counts. National accounts of the practice and role of journalism often ignore the case that there is no single journalistic model operating within a single country and there are significant differences between journalism in television and the press and within the press (Mancini, 2005: 82). By empowering national differences "the discussion of norms recedes into the background" (Joesphi, 2005: 578). Mitchell Stephens (2000?) points out that "countless notions" about journalism theory and practice that have "drifted across borders in what has always been a cosmopolitan business" and by locating our studies within national boundaries we "obscure crucial connections and lineages and ignore telling comparisons". Classifying practices and performances within different countries is down-graded in the effort to indicate that the Anglo-American model does not fit the rest of the world. Daniel Hallin and Paolo Mancini (2004) seek to redress this with their classification of national media systems in Western Europe. Their research identifies three models: Liberal, Democratic Corporatist and Polarized Pluralist. As a result of a number of factors journalism in each of these types of system is conceptualised and practiced in different ways. The authors "relegate the dominant liberal model to being just one amongst several" and present a "decisive challenge" to the universalistic approach (Joesphi, 2005: 582). 
Hallin and Mancini also raise a fundamental question about the relationship between the theory and practice in the discussion of journalism. They draw attention to a normative bias which blurs the boundaries between what journalism ought to be and what journalists do in practice. The Anglo-American model layouts a view of journalism that is "rarely attained" and is "far removed from what is actually practiced in newsrooms around the world" leading some to wonder why the profession and academy still consider it useful (Joesphi, 2005: 576). Professional journalism education and scholarly study prefer to focus on the normative dimension, eschewing analysis of what journalists do and why. For example, objectivity is a cornerstone of the professional model in spite of variety of difficulties that have been identified by journalists and scholars in the attempts to put the concept into practice. Hallin and Mancini emphasise the importance of building models based on empirical evidence rather than normative assumptions. They argue that cross cultural analysis helps to sensitise researchers "to variation and similarity, and thus can contribute powerfully to the refinement of our conceptual apparatus" (Hallin and Mancini, 2005: 216). By comparing how journalism is conceived and practiced across and within national boundaries we can better identify the factors that shape how journalism is conducted and offer fuller, less particular and less ethnocentric explanations about how and why certain practices constitute what journalists do.

European journalism is traditionally studied through the frame of the nation state. As has been said, the style, form and role of journalism are shaped by the society, politics and culture within which the profession is understood and practiced. Nevertheless it is possible to identify several features that are common to journalism in most European countries and more significantly which are absent from the type of journalism that is practiced in Britain and America. The Anglo-American hegemony has led to scholars portraying the European model of journalism as regressive and old-fashioned; a model of how not to practice journalism. European journalism is not considered as part of the "unique discursive revolution" that occurred in Britain and America in the mid- 
Victorian period (Chalaby, 1998). It is represented as resistant to giving up the old ways and committed to methods, practices and attitudes that are the antithesis of what modern journalism should be. Above all, it is seen as partisan and political, an anathema in a world in which Anglo-American journalism is seen as the best and only way of organising practice. While these features do not necessarily constitute a model that applies to ever European country, the similarities in the practice of journalism across the continent do represent an alternative approach to doing journalism. It is argued that the European way of doing journalism is being eroded in the wake of globalisation and the encroachment of Anglo-American values. However, this shift does not necessarily result in a fundamental change in what journalists do. Many European journalists, in spite of the political and technological changes in the working environment, remain wedded to their ways of doing journalism. A growing commitment to the AngloAmerican approach of objective, straightforward and informative reporting may be apparent in the rhetoric of European journalism but it is not reflected in the practice of journalism in many European countries.

\section{The European Model of Journalism}

There are several features which are seen as distinguishing the European model of journalism. The close relationship with politics and the literary world are regarded as particularly significant. Journalists in Europe are seen as closely linked to political parties and factions. Giovanni Bechelloni (1980: 228-43) describes how Italian journalists have traditionally been "political clients" whose close ties to political parties enable them to benefit financially and in terms of their job security from political protection and patronage. Mancini (2000: 266) states that "Italian journalists are advocates, linked to political parties, and very close to being active politicians themselves". The political fragmentation of European societies produces a more complex political situation for the journalist to negotiate, forcing them to embrace the political. France is typical of the multiparty political systems that characterise most European countries. The wide range of politi- 
cal positions, parties and ideologies preferences journalism based on political opinions rather than news and information (Chalaby, 1996: 319). Journalism in the Nordic countries is closely tied to politics albeit in a different way from Mediterranean countries. Strong corporatist traditions and a high degree of social and political consensus have tied journalism to politics. In most European countries journalism and the media are the "voices of organised groups" (Mancini, 2000: 271). Whether it is through "pillarisation" in the Netherlands, "socially relevant groups" in Germany or "lottizzazione" in Italy journalism has been closely attached to politics and the promotion of ideology. This contrasts with Britain and America where it is far easier for journalists to exercise political neutrality and objectivity, because of the limitation of political choice arising from the two party political system (Chalaby, 1996: 319). For European journalists political neutrality and objectivity are "almost impossible within an intricate and fragmented panorama in which a greater number of political forces act and in which even the slightest shades of meaning in a story risk stepping on the positions of one of the forces in the political field" (Mancini, 2000: 273). The greater ideological and political commitment of European journalism is seen in the tradition of advocacy. Renate Kocher (1988) found that German journalism places greater emphasis on opinion and less on news. German journalists, according to Kocher's study, define their primary role as that of being "missionaries" and see their profession as "a species of a political and intellectual career". They are more comfortable in advocating a political position than their British colleagues who tend to define their role as "transmitters of facts" and "neutral reporters of current affairs".

The political and ideological nature of European journalism is only partly explained by the nature of European political systems. The slow development of the economic conditions that enabled Anglo-American journalism to detach itself from politics and the State is also significant. Market forces played an important and earlier role in the US and British press than they did in Europe (Chalaby, 1996: 320). The rapid growth of the industrial capitalism in nineteenth century Britain and America enabled the press to 
build up a separate source of revenue, mainly through advertising, that allowed it to become independent of the state and political parties. The autonomy of the press from the political sphere encouraged a de-politicisation of journalism, and the need to increase advertising income saw the norms of objectivity and neutrality enhanced as newspapers tried to reach out for more readers. By contrast, the growth of advertising revenue and market forces in the European press were much slower. Jean Chalaby (1996: 321) describes the reluctance of French industrialists to spend money on advertising while Robert Lumley (1996: 202-4) notes how small readerships and slow urbanisation held back the emergence of an Italian press. The result is that in Europe the press remained dependent for longer on the State and political parties.

European journalism is the strong roots the profession has in the literary world (Mancini, 2005: 83-7). Erik Neveu (2001: 12) notes that, for most of the nineteenth century, working for a French newspaper was a stepping stone for a "real career" in literature or politics. Chalaby (1997: 638) describes French journalism as a "provisional occupation" with young men and women seeing it as "the first step towards a brilliant literary career". Many of the key figures of nineteenth century journalism in France were great novelists such as Emile Zola, Victor Hugo and Honore de Balzac. The tradition of journalism in France is associated with the writer rather than the reporter (Neveu, 2001: 14). Hence the compiling of facts has been secondary to serious articles or essays discussing politics and literature. The French journalistic tradition does not draw a sharp line between facts and interpretation, and articles "freely mixed news with opinions" (Chalaby, 1996: 311). The most celebrated form of journalism writing is the "commentary' which combines analysis and comment on a topic from a specific, usually political, point of view (Chalaby, 1996: 315). "French journalism has always been more a journalism of expression than a journalism of observation: it gives precedence to the chronicle and the commentary over summary and reportage" (Albert (1983) quoted in Hallin and Mancini, 2004: 98). 
Polemical writing dominated Italian newspapers well into the post war period. Political commentaries known as pastone romano appeared daily on the front page in the 1950s and 1960s (Porter, 1983: 10-11). A review of major political developments of the day written by a leading journalist was the dominant form of political reporting in the Italian press. Their equivalents appear in the French and Spanish newspapers under the titles of chronique and cronica respectively (Hallin and Mancin, 2004: 101). The German tradition of journalism was "unfamiliar with the distinction between factual reporting and commentary" and also emphasised literary quality (see Kleinsteuber and Weischenberg, 2001). According to Wolfgang Donsbach and Bettina Klett (1993: 57) '... the opinionated editor and commentator was seen as the epitome of the journalistic profession' in Germany with German journalists "more likely to make news decisions on the basis of their subjective beliefs". European journalism is "more inclined to comment and evaluation, to interpretation and judgement and pays more attention to 'literary' writing than to the simple and terse telling of the facts" (Mancini, 2005: 83). Today we are likely to find the description of events and their interpretation and analysis overlapping in the pages of the European press (Mancini, 2005: 85). Points of view are commonly taken and the selection of subject matter reflects the literary roots of journalism, gravitating to the more highbrow topics in politics, the arts, culture and the social sphere.

\section{European Newsrooms}

The difference between European and Anglo-American journalism is not only a matter of how journalists understand their role in society and how they approach their work, it is also manifest in the organisational structures in which they work. Newsrooms in many parts of Europe operate very differently from what happens in Anglo-American offices. In Britain and America centralised newsrooms are favoured with a high division of labour apparent in the organisation of the newsroom (Esser, 1998: 378). More people are employed to undertake a wider range of tasks. At least four different professional groups have been identified as 
performing the functions of the newsroom - - reporters, subeditors, leader writers, page planners/designers (cited in Esser, 1998: 379). Reporters are divided into general reporters and specialist correspondents and usually organised in 'beats' or 'desks' such as business/finance, home, foreign and sports. Background pieces, analysis and interpretation are for the most part written by feature writers who are allowed to present a point of view. In recent years opinion has become the remit of columnists who have increased significantly in number. There is a "distinct separation between the tasks of the reporter, who collects the news externally ... the sub-editor in the editorial office, who corrects texts and formulates titles and headlines and the commentator or 'leader writer' who contributes texts expressing opinions" (Kepplinger and Kocher, 1990: 292). News gatherers and news processors, are often segregated, working in different departments (Esser, 1998: 389). Anglo-American newsrooms are hierarchical structures, reflecting the emphasis placed on the separation of fact and comment as well as the importance of journalism as a business demanding the smooth operation of the production process.

Newsrooms in Europe are less centralised and the journalist performs a wider range of tasks. The division of labour in European newsrooms is less apparent. In many parts of Europe one term 'redakteur' in Germany, 'redactar' in Spain, 'redacteur' in France - - is used to describe all those working in the newsroom. The European journalist is more likely to perform the whole range of functions, news gathering and reporting, writing editorials and technical production that are carried out by several individuals in Britain and the US (Esser, 1998: 379; Kepplinger and Kocher, 1990: 292). German, French, Spanish and Italian journalists are less aware of the fundamental division inside Anglo-American newsrooms between reporters and sub-editors. In Europe the journalist will be involved in every aspect of the operation of the newsroom, investigating, editing, reporting, commentating and layout as well as building contacts with external sources of information. The organisation of European newsrooms reflects the importance attached to editorial commentaries as a yardstick 
of quality in journalism and the role of the journalist in conveying opinion. Compared to Anglo-American newsroom, there are fewer structures to prevent journalists from acting out their 'advocacy' or 'missionary' roles.

\section{Status of Journalism}

The close ties between journalism and politics and literature in many parts of Europe reflects the relatively low status of the profession. Max Weber in 1918 described journalists as belonging to "a sort of pariah caste" (quoted in Tunstall, 2001: 25). For most of the nineteenth century journalism was treated with disdain and fear, a lowly occupation which no-one with any ability would willingly enter (Lee, 1976). To earn a living, journalists had to supplement their income in other ways. They were as a consequence open to bribery and political patronage. It is estimated that between 1871 and 1913 the French government spent between one and two million francs per annum on seeking to influence journalists who were in the habit of regularly taking bribes from bankers, financiers and foreign embassies to conceal information or promote share sales and business ventures (Chalaby, 2002: 80). Selected French journalists were in receipt of money from the government until well into the 1960s. Bribery and graft played their part in the development of modern Italian journalism, even though Italian journalists were relatively well paid compared to most of their European counterparts (Porter, 1983: 29-34). In Portugal, the low status of journalism was perpetuated by dictatorship. The Salazar and Caetano regimes reduced the occupation to little more than a 'clerical sub profession' whose main task was "to transcribe or summarise statements issued by government departments of ministerial offices" (Seaton and Pimlott, 1980: 179). As a result Portuguese journalism was a low paid occupation with little professional pride that offered no opportunity for talented individuals. It was only in the wake of the revolution in 1974 that it began to develop greater professionalism and more autonomy. However, this only came after journalists had played their part in the anti-imperialist, anti-colonial and anti-fascist struggle initiated by the Portuguese revolution 
(Hallin and Mancini, 2004: 103). Similar situations pertained to Spain and Greece in the wake of the collapse of military dictatorships (see Papatheodorou and Machin, 2003).

Journalism in Britain and North America was rescued from low esteem and corruption in the late nineteenth century by the demands of commerce and business. The failure of the press to attain a sufficient level of financial independence made it more difficult for journalism in countries such as Italy, France, Spain, Portugal and Greece to develop as a profession and establish its autonomy from the state and political groupings (Hallin and Papathanassopoulos, 2002: 183; Papatheodorou and Machin, 2003: 34). The political and literary roots of journalism in southern Europe were deeper. Professional organisations and journalists' unions are generally weaker in the Mediterranean countries. Traditionally they were linked to political parties and membership was low. Where autonomous organisations were established, as in Italy, the main concern was the control of access into the profession rather than "advancing common standards of professional conduct” (Hallin and Mancini, 2004: 112). In Northern European countries - Scandinavia, Netherlands, Germany and Austria - the strong political affiliations of the press did not correspond with the under-development of the profession of journalism. Journalists' unions emerged in the late 19th and early 2oth century to play an important role in establishing rules and regulations and thus facilitated the emergence of a journalistic culture which transcended political affiliation (Hallin and Mancini, 2004: 177). In many European countries there are editorial statutes that protect the independence of journalists. French journalists under the clause de conscience have the right to leave their newspaper with compensation if the ideological position is changed (Hallin and Mancini, 2004: 116).

\section{The Demise of the European Model}

The Anglo-American model is seen as increasingly dominant in European media systems, eroding the differences which characterise journalism in these societies. There has been a shift to a 
more "information-oriented journalism" (Hallin and Macini, 2004: 99). Mass media associated with political parties and other organised social groups have declined. Replacing them are commercial media "whose purpose is to make a profit by delivering information and entertainment to individual consumers and the attention of consumers to advertisers" (Hallin and Mancini, 2004: 252). The result has been that the "journalism of expression" has been displaced to be replaced by Anglo-American practices. In some countries such as Germany and Austria the American way of doing journalism was imposed by the Allies to ensure that Nazism and Fascism would not reappear. The separation of fact from comment was established as central to the new press system in post war Germany (see Humphreys, 1994). In other parts of Europe the Anglo American model was disseminated through training programmes, textbooks and Hollywood films dealing with the profession (Mancini, 2000: 268). The international news agencies, dominated by US and UK companies, not only provide most of the world's foreign news but also serve as vehicles to bring Anglo-American news values and news practices into newsrooms around the world (Tunstall, 1977: 45-6). Hallin and Mancini (2004: 258-9) note that journalists are heavy consumers of Anglo-American media. Journalists in many parts of Europe, as elsewhere in the world, regularly tune into the BBC and $\mathrm{CNN}$ as well as read global business publications such as The Economist, Wall Street Journal and Financial Times and news magazines such as Time and Newsweek. A study of Greek international news gatekeepers identified the influence of US news magazines as well as CNN International in shaping their organisations' concept of newsworthiness (Roberts and Bantimaroudis, 1997). It was therefore no surprise that the newly liberated countries of Eastern Europe embraced the Anglo-American model following the demise of Communism in the late 1980s (Pottker, 2005).

The arrival of television is also seen as having had an impact on the practice of journalism in Europe. Broadcast journalism played a crucial part in challenging the European model by helping to weaken the political foundations on which it was based. Wigbold (1979) describes how the rise of television is associated with the 
'de-pillarisation' of the Dutch society and the media. He argues that the introduction of a single television channel into the homes of people who had been previously segregated from each other not only introduced them to ideas, views and opinions from which they had been isolated but also showed them that their fellow citizens were not as alien and different as they had been encouraged to believe. Television "hastened the birth of a new unity" (Wigbold, 1979: 201). It also brought into being a new broadcasting organisation, TROS. Formerly broadcasting from a pirate transmitter from an offshore island TROS eschewed politics, focusing instead on light entertainment. Its aim was to attract a large number of viewers instead of providing a service for a particular group or community. Its success led to other broadcasting organisations emulating TROS with the corresponding de-politicisation of Dutch television. Woolton (1992) argues that the explosion of news in the 1980 s brought about by the rapid growth of the broadcast media, especially television, played a crucial role in helping French journalists to develop greater freedom of work and expression. The state has found it more difficult to regulate and control the private TV channels. Greater competition led to the adoption of practices as well as programmes from the US and the UK. Bourdon (2000) outlines how European broadcasters "consciously tried to imitate American newscasters". Satellite technology made audiences around the world more attuned to American production values and journalistic techniques which then increased the pressure on journalists in European television to do things the Anglo American way. Television enabled journalists to assert their independence, but made them more open to the practices and values of US journalism. Above all, more emphasis was attached to lack of partisanship in the collection, processing and dissemination of news and information.

Hallin and Mancini (2004: 272-3) identify several other factors that helped to break down the close connection between journalists and politics, making European journalists more similar to their Anglo American colleagues. Rising educational levels have led to the profession incorporating into their practice more criti- 
cal perspectives drawn from the social sciences and humanities. The development of journalism schools and journalism training has improved professional standards across the continent as well as making European journalists more aware of Anglo American methods. Higher levels of educational attainment have increased the prestige of journalists. Commercialisation has also increased the social and professional status of journalists. Papathanassopoulos (2001: 512) describes how the rise of market-led journalism in Greece is linked to higher salaries and increased authority and resulted in Greek journalists becoming more professional, more responsible and more detached in their reporting. The increase in the size of media organisations, as well as the development of new technologies for gathering information, has enhanced the resources at the disposal of journalists and their capacity to interrogate those in positions of power.

Evidence to support the claim that European journalism is becoming less distinctive is found in surveys of journalists' opinion of their profession. The commitment of German journalists to the "missionary" role is seen to have wavered in the 1990s. A survey of over 1500 journalists in Germany concluded that "the superiority of a 'missionary' self-concept over a 'bloodhound' one did not reflect the reality of Germany in the early 1990s" (Schoenbach et al., 1998: 225). Weischenberg et al. (1998: 251) question the extent to which German journalists ever adopted a missionary role, concluding from their study that there has been "a convergence in journalism in western liberal democracies". This finding is in keeping with the work of Spichal and Sparks (1994) who, based on an examination of journalism students in 22 countries, argue that there is a universal set of professional values emerging, particularly regarding autonomy and objectivity. However, not all survey material points in the direction of the emergence of a common approach to the practice of journalism. The notion of common values among journalists is challenged by Weaver (1998) whose comparative analysis of journalism across national boundaries concludes there are no common values and purposes of the profession, other than bringing news to the public's attention as quickly as possible. Weaver (1998: 468) identified considerable 
disagreement over the importance of analysis and acting as a 'watchdog' on government.

Examining what journalist do raises doubt as to how far the Anglo-American model of journalism has become prevalent in Europe, as well as about the extent to which European journalism has been de-politicised. Cultural factors have been identified as acting as a barrier to the adoption of Anglo-American styles of journalism. Graham-Holm (1999) draws attention to the ways in which Danish journalism has resisted the style and practices of American TV news. She describes how the deep rooted traditions of Danish society have laid down powerful cultural boundaries which "protect Danish TV journalism from outside influence, boundaries so powerful that penetration is a slow process". The refusal of news reporters to 'sign off', that is to conclude their report by telling the audience who and where they are, is one of many examples of resistance to the adoption of AngloAmerican style, content and presentation cited. Papathanassopouolos (2001: 507) argues that political and cultural particularities make it "difficult to develop a culture of journalistic professionalism faithful to the American model" in Greece. While most Greek journalists say they adhere to the neutral and objective model of journalism, in practice facts and comments are freely mixed together in Greek news reporting. Commercialisation and a more market-oriented news media are changing Greek journalism, with the growing influence of television reporting leading the way, but at times of "intense political contention" the political affiliations of journalism and the media are made apparent. Unabashed partisanship remains a feature of the Greek press which is "in some cases laced with adjectives that in most western media would be considered incompatible with fairness" (Papathanassopoulos, 2001: 511). Mancini (2000: 272-3) describes how objectivity "has not found a comfortable abode in Italy". Italian journalists adhere to the concept of objectivity as a "purely external legitimation in keeping with the perceived model of professional canons" but their journalism is practised in a society which is highly politicised from top to bottom. Politics pervades Italian society, "dominating and influencing many social sys- 
tems: economics, the judiciary system and so on". People's participation in politics is high and in this situation "journalists ... cannot be abstracted and detached from the other social powers" as required in the Anglo-American model.

It is also the case that many European journalists disapprove of and are unwilling to use the controversial techniques of investigative journalism, including pretending to be someone else to gain information, quoting from confidential government documents and infiltrating organisations to acquire information. German journalists are seen as particularly reluctant to deploy such tactics. A survey found that only $19 \%$ of German journalists would pretend to be someone else to acquire a story, compared to $47 \%$ of British reporters (cited in Kleinsteuber and Weischenberg, 2001: 290). Some argue this is not an indication of the 'weak' tradition of investigative reporting in Germany but a reflection of higher standards of ethical behaviour and greater reticence in discussing professional practices. They cite the example of German writer and reporter Gunter Walraff as one of the best known 'heroes' of investigative journalism. However, Walraff's career of infiltrating and exposing the works of a number of organisations, including Germany's leading newspaper, Bild, which he accused of faking stories, has been regarded as an "undesirable" part of the profession by some journalists (Walraff, 1978).

\section{Relevance of European Model}

Determining the extent to which European journalism is becoming more Anglo-American in style and practices is far from easy. European journalism training programmes are incorporating Anglo-American values and methods in their curricula; commercialisation shifts journalism from a profession steeped in the world of politics to one which produces entertainment and information for sale to the highest bidder; technological change enhances the sense of common practice and standards. Yet individual journalists in many European countries maintain close connections with political partisanship, are still oriented to commentary, interpretation and advocacy and remain committed 
to 'literary' writing. Long discursive commentaries still form the backbone of many European newspapers. Mancini (2000) highlights limits to the transformation of European journalism, stressing that the extent to which the Anglo-American model has taken hold in Europe depends on the peculiarities of the social structures and contexts of different European countries. He notes that in practice journalists conform to the traditions of their particular countries, which in most European nations emphasise the political commitment or involvement of journalism. There is a "striking contradiction" between a "sort of theoretical wisdom diffused among most of the professionals" and real practice (Mancini, 2000: 266). The extent to which journalists remain committed to traditional ways of doing journalism is hidden by the universalistic approach that much scholarship takes to assessing journalism.

Much of the empirical material that has been gathered about how journalists perceive their role and how they practice their profession is from surveys (Sparks and Spichal, 1994; Weaver, 1998). While amassing a mountain of facts and figures about the background and profile of journalists this source of information has its blind spots. Relying on what people tell you, as journalists over the years have found out, is problematic. There is a gap between what journalists' say they do and what they actually do. Journalists' perceptions of what they do are shaped by the normative ideals of the Anglo-American model, often leading them to ignore much of what they do in practice that falls outside or contradicts the model (Hallin and Mancini, 2004: 13). Their responses are "heavily shaped by normative expectations and aspirations” (Hallin and Mancini, 2004: 303; also see Joesphi, 2005). While surveys may provide insights into what journalists think about their profession they do not necessarily provide a reliable guide to how they act. The drawing up of surveys is also skewed by the normative expectations of the Anglo-American model which are sometimes responsible for "moulding the questionnaire and in turn shaping the answers" (Joesphi, 2005: 584). As Hallin and Mancini stress there is a need for more ethnographic studies of newsroom cultures and observational studies of how 
news and information are gathered which will enable scholars to assess the responses of journalists by comparison with what they do.

Forces of change are pushing European journalism towards more news driven, fact oriented, objective practices. But they have not eliminated the political and literary nature of the profession in Europe. In fact it is possible to argue that the technological, economic, social and political changes that are taking place are reasserting the importance of subjectivity and partisanship in journalism. The concept of objectivity has never comfortably fitted into the practice of journalism, anywhere. At the time when objectivity established itself as the guiding principle of American journalism in the 1920 many commentators expressed their reservations about the limitations of fact centred reporting (for example, Lippmann, 1922). Schudson (1978) describes how objectivity came to be seen as a form of bias in America from the 1950 s and 1960s onwards. Remaining detached, simply reporting the 'facts', reproduced a vision of social reality that was partial. The performance of the American journalists in reporting McCarthyism, the Cold War, civil rights and the early days of the US involvement in Vietnam gave rise to calls for 'advocacy journalism'. Fact centred reporting was seen as inadequate in face of the moral and political dilemmas of modern society A new generation of American journalists called for a more committed approach "powered by feeling as well as intellect” (Schudson, 1978: 187). In more recent times broadcast journalists such as the BBC's Martin Bell have called for a "journalism of attachment" which "cares as well as knows; that is aware of its responsibilities; that will not stand neutrally between good and evil, right and wrong, the victim and the oppressor ..."(Bell, 1998: 16). Such calls for involvement are reinforced by commercial needs, which are driving journalism to sensationalism and partiality as much as they are to notions of factuality and objectivity. Advocacy of greater freedom for partisanship in TV news by companies such as Fox TV through the relaxation of the legal requirement of balance are increasingly prominent in the profession. Behind the commitment to factuality Anglo-American journalists like their European 
counterparts are involved in a process of interpretation, explanation and commentary. It is "something of a sham" to claim that political considerations do not play a part in Anglo-American reporting (Stephens, 1997: 261). The growing prevalence of opinion and personal columns in British and American newspaper could be seen as yet another indication of the decline of the AngloAmerican model. The European model of journalism may be more relevant in a world where the strategic ritual of objectivity is increasingly exposed.

\section{Conclusion}

Journalism as practice in Europe is distinctive. The emphasis on partisanship, advocacy, interpretation and explanation and a literary style are the basis for this. This distinctiveness is changing as Anglo-American practices have become incorporated into the profession. However, the extent of the changes can be exaggerated. Many European journalists remain wedded to what is often portrayed in the literature as the 'old ways' of doing journalism, which encourages journalism's involvement in and political engagement with society. There are problems in labelling this form of journalism as 'European' - as well as labelling fact based, objective journalism as 'Anglo-American'. Journalism history identifies these two different approaches as competing ways of doing journalism which are found in different measures in all societies. The so-called Anglo-American model became more prevalent from the late $19^{\text {th }}$ century onwards through the industrialisation and commercialisation of the profession as well as the breakdown of the old political and social order. Its penetration into European societies was slower due to the pace of economic, industrial and political change. Political journalism in a variety of forms remained more embedded in European societies, although it is important to stress it never disappeared in British or America. Today it is possible to see a move back towards practices of journalism which are labelled European, as political engagement and involvement, greater interpretation and explanation are called for in helping the profession to adjust and navigate the complexities, confusions and changes of the information age. 


\section{NOTES}

1. This article is based on a talk given at the Hogeschool at Utrecht in honour of the retirement of Professor Marianne Peters, March 6, 2006 and Chapter 5 of my book European Media Studies published by Arnold in 2005.

\section{REFEREN CES}

Albert, P. (1983). La Presse Francaise, Paris: La Documentation francaise. Bechelloni, G. (1980). 'The Journalist as Political Client' in A. Smith (ed.), Newspapers and Democracy, Cambridge, Massachusetts: The MIT Press.

Bell, M. (1998). 'The Journalism of Attachment' in M. Kiernan (ed.), Media Ethics, London: Routledge.

Bourdon, J. (2000). 'A History of European Television News: From Television to Journalism, and Back?' Communications, Vol. 25, No. 1, pp. 6184.

Chalaby, J. (2004). 'Scandal and the Rise of Investigative Reporting in France', American Behavioural Scientist, Vol. 47, No. 9, pp. 1194-1207.

Chalaby, J. (2002). The de Gaulle Presidency and the Media: Statism and Public Communications, London: Palgrave.

Chalaby, J. (1998). The Invention of Journalism, London: Macmillan.

Chalaby, J. (1996). 'Journalism as an Anglo-American Invention: A Comparison of the Development of French and Anglo-American Journalism, 1830s-1920s', European Journal of Communication, Vol. 11, No. 3 , pp. 303-326.

Curran, J. and Myung-Jin Park (eds.). (2000). De-Westernising Media Studies, London: Routledge.

Downing, J. (1996). International Media Theory, London: Sage.

De Burgh, H. (2005). Making Journalists, London: Routledge.

Deuze, M. (2005). 'What is Journalism? Professional identity and ideology of journalists reconsidered', Journalism Theory, Practice \& Criticism, Vol. 6, No. 4, pp. 442-464.

Donbash, W. and B. Klett (1993). 'Subjective objectivity: How journalists in four countries define a key term in the profession', Gazette, No. 51, pp. 53-83.

Esser, F. (1998). 'Editorial Structures and Work Principles in British and 
German Newspapers', European Journal of Communication, Vol. 13, No.3, pp. 375-405.

Graham Holm, N. (1999). American Influence on Danish Journalism Center for Journalistik og Efteruddannelse, Danmarks Journalisthøjskole http://www.cfje.dk/cfje/vidbase.nsf/(VBFriTekstMultiDB)/FD 279AC9F863C3D8C125676100312D27?OpenDocument

Hallin, D. and Macini, P. (2004). Comparing Media Systems, Cambridge: Cambridge University Press.

Hallin, D. and Papathanassopoulos, S. (2002). 'Political clientelism and the media: southern Europe and Latin America in comparative perspective', Media, Culture \& Society, Vol. 24, pp.175-195.

Hoyer, S. and H. Pottker (2005). Diffusion of the News Paradigm, Göteborg: Nordicom.

Humphreys, P. (1994). Media and Media Policy in Germany: The Press and Broadcasting since 1945, Oxford: Berg.

Humphreys, P. (1996). Mass Media and Media Policy in Western Europe, Manchester: Manchester University Press.

Joesphi, B. (2005). 'Journalism in the Global Age: Between the Normative and Empirical' Gazette: The International Journal for Communication Studies, Vol. 67 No. 6, pp. 575-590.

Kepplinger, H.M. and R. Kocher (1990). 'Professionalism in the Media World?' European Journal of Communication, No. 5, pp. 285-311.

Kleinsteuber, H. and Weischenberg, S. (2001). 'The Contradiction of Journalism in Germany' in J. Tunstall (ed.) Media Occupations and Professions, Oxford: Oxford University Press.

Kocher, R. (1986). 'Bloodhounds or Missionaries: Role Definitions of German and British Journalists', European Journal of Communication, Vol. 1, pp. 43-64.

Lee, A. (1976). The Origins of the Popular Press 1855-1914, London: Croom Helm.

Lippmann, W. (1922). Public Opinion, New York: Free Press.

Lumley, R. (1996). 'Peculiarities of the Italian Newspaper' in D. Forgacs and R. Lumley (eds.), Italian Cultural Studies: An Introduction, Oxford: Oxford University Press.

Mancini, P. (2005). 'Is There a European Model of Journlaism?' in H. De Burgh (ed.), Making Journalists, London: Routledge.

Mancini, P. (2000). 'Political complexity and alternative models of jour- 
nalism' in J. Curran and Myung-Jin Park (eds.), De-Westernising Media Studies, London: Routledge.

Newton, K. and Artingstall, N. (1994). 'Government and Private Censorship in Nine Western Democracies in the 1970s and 1980s' in I Budge and D. McKay (eds.), Developing Democracy, London: Sage.

Neveu, E. (2001). Sociologie du Journalisme, Paris: Edition La Decouverte.

Palmer, M. (2001). 'Journalists and Media Professionals in France' in J. Tunstall (ed.), Media Occupations and Professions, Oxford: Oxford University Press.

Papathanassopoulos, S. (2001). 'Media Commercialization and Journalism in Greece' European Journal of Communication, No. 16, pp. 505521.

Papatheodorou, F. and D. Machin (2003). 'The Umbilical Cord That Was Never Cut: The Post-Dictatorial Intimacy between the Political Elite and the Mass Media in Greece and Spain' European Journal of Communication, No. 18, pp. 31-54.

Porter, W. (1983). The Italian Journalist, Ann Arbor: University of Michigan Press.

Pottker, H. (2005). 'Epilogue. Perspectives on the Development of the News Paradigm. The Quest for Autonomy' in S. Hoyer \& H. Pottker (eds.), Diffusion of the News Paradigm 1850-20oo, Göteborg: Nordicom.

Roberts, M. and P. Bantimaroudis (1997). 'Gatekeepers in International News: the Greek Media', Press/Politics No. 2, pp. 62-76.

Schoenbach, K., D. Stuerzebecher, \& B. Schneider (1998). 'German Journalists in the Early 1990s: East and West' in D. Weaver (ed.), The Global Journalist: News People Around the World Cresskill, New Jersey: Hampton Press.

Schudson, M. (1978). Discovering the News: A Social History of American Newspapers, New York: Basic Books.

Seaton, J. and B. Pimlott (1980). 'The Role of the Media in the Portuguese Revolution' in Smith, A (ed.), Newspapers and Democracy, Cambridge, Mass: MIT Press.

Spichal, S. and C. Sparks (1994). Journalists for the $21^{\text {st }}$ Century Norwood, New Jersey: Ablex.

Stephens, M. (1997). A History of News, Fort Worth: Harcourt Brace.

Stephens, M. (nd). Call for an International History of Journalism 
http://www.nyu.edu/classes/stephens/International\%20History\% 20page.htm (accessed 12/6/o6).

Tunstall, J. (2001). Media Occupations and Professions: A Reader, Oxford: Oxford University Press.

Tunstall, J. (1977). The Media are American, London: Constable.

Tunstall, J. and D. Machin, (1999). The Anglo American Media Connection, Oxford: Oxford University Press.

Wallraff, G. (1978). Wallraff: The Undesirable Journalist, London: Pluto Press.

Weaver, D. (ed.) (1998). The Global Journalist: News People Around the World Cresskill, New Jersey: Hampton Press.

Weischenberg, S., Loffelholz, M and Scholl, A (1998). 'Journalism in Germany' in Weaver, D. (ed.), The Global Journalist: News People Around the World Cresskill, New Jersey: Hampton Press.

Wigbold, H. (1979). 'Holland: The Shaky Pillars of Hilversum' in A. Smith (ed.), Television and Political Life: Studies in six European countries, London: Macmillan.

Woolton, D. (1992). 'Journalists: The Tarpeian Rock is Close to the Capitol', Journal of Communication, Vol. 42, pp. 26-41. 